\title{
Culture-Based Education: An Alternative For Overcoming The Noble Value Degradation in Globalization Era
}

\author{
Muhiddinur Kamal ${ }^{1}$, Nofri Andy N², Syafwan Rozi ${ }^{3}$, Heru Permana Putra ${ }^{4}$, Muhamad Rezi ${ }^{5}$. \\ \{muhiddinurkamal@gmail.com ${ }^{1}$, nofiandy.n@gmail.com², sa_ra_de@gmail.com ${ }^{3}$, \\ che.heru@gmail.com ${ }^{4}$, rezineddin@gmail.com $\left.{ }^{5}\right\}$
}

Faculty of Education and Teaching Institut Agama Islam Negeri (IAIN) Bukittinggi Padang, Indonesia ${ }^{1}$ Faculty of Ushuluddin Adab \& DakwahInstitut Agama Islam Negeri (IAIN) Bukittinggi, Indonesia ${ }^{2.3,4,5}$

\begin{abstract}
Nowadays, globalization spreads around the globe as an inevitable necessity. It reaches places over the world and even remote villages. Globalization, marked by new discoveries and innovations, has greatly facilitated the life of humankind, so they can easily communicate from different parts of the world. Advances in information technology, especially those that open various global accesses, have made the world increasingly narrow (shrinking globe). The era of globalization has brought many conveniences for humankind in technology and information. This era seems to make the world without borders, but it also brings many negative effects. Another phenomenon of globalization is the decreasing tren in young generation's understanding of noble cultural noble values embraced and upheld by the society. It leads to the lack practice of such values among young generation who tend to adhere to global cultures that are in some parts incompatible with the local and national ones. Education as a process of civilization, enculturation, and acculturation is also a medium for cultural conservation, transmission, and preservation of national culture along with its noble values. Culturebased education is seen as a vehicle for understanding, application, and preservation of noble values to maintain them againts the eroding tides of globalization. Culture-based education can be implemented can be applied in three ways: learning about culture, learning with culture, and learn through culture.
\end{abstract}

Keywords. Globalization, Cultural Education, Noble Cultural Values.

\section{Introduction}

The era of globalization not only brings a lot of convenience in life but also has negative impacts for humankind. Globalization has disrupted all established aspects of life that the adaptive power of a nation in such system is greatly affected by the rapid changes.[1]Various crises arise as one of the effects of globalization. The multidimensional crisis hit the world in the aspects of $\mathrm{f}$ politics, economy, unity and intimacy. The religious values begin to diminish, and cultures as well as ideology were abandoned. The national material and spiritual development is also stalled, discontinued, unlinear, and unpredictable.[2]

The era of globalization brings opportunities and challenges. There are the three most important features in globalization as open competition, interdependency, and competitiveness. 
The open competitive condition of globalization increasingly widespread and involve various dimensions of life. Competition is increasingly open and widespread which has an impact on the level of complexity of the ever increasing competition. Globalization also leads to the increasing dependency of one party to another. Finally, globalization demands strong competitiveness between one country and others.[3]

Globalization with its aspects of openness and liberalization tends to ignore the boundaries of the cultural values and character of a nation. The depletion of these cultural values slowly erodes nationalism as the identity of a nation. Free sex, juvenile delinquency, bullies, drug abuse, pornography, theft, and destruction of someone else's property are some of the current social problems. Globalizations and modernization affect both social and individual structures within society. Cultural practices and behaviors are influenced that people run a different way of life. Often, they do not use religion as the foundation of their behavioral practices. Therefore, it is expected that cultural-based education can be taken as a benchmark for the students to behave in a society. It is necessary to find appropriate approaches that can preserve cultural values. There is a chance that hegemonic polarization dominated by superpower countries replaces the cultural values which may not meet the local beliefs.

In light with the abovementioned issues, the era of globalization with its consequences and challenges brings impact on noble cultura values and national culture, so special attention and high concern for the current of globalization needs to be given. To that aim, national capital and strength should to be reinforced in the form of culture-based education in order that the future generation will not deeply be drawn into negative impact of globalization and lose their noble cultural values.

\section{Culture and Education}

Education has two main functions, transfering values and transfering knowledge. Through the world of education, humankind is expected to transfer the values, norms, and noble characters from one generation to the next generation. [4] Education can be defined as a process in which a person develops attitudes and other forms of social behaviors.[5]

Education is a dynamic force and energy in human life. It affects theur intellectual, emotional, and spiritual intelligence. In other words, education is the energy in humans that affects the aspects of their personality.[6]

Explicitly, it is understood that the aim of education is not only to shape students to be skillful persons but also to make them religious, independent, creative, and responsible.

Education is efforts designed and done systematically to help students understand human behavior related to God the Almighty, self, other people, environment, and nation. It is reflected from their thoughts, attitude, feelings, words, and actions which all are based on the norms, cultures, laws, and values in the society.[7]

The essence of an education is learing. It can take place naturally through the individuals' interpretation of their life experience meaning. Whether they are fun or not, all experiences can be a learning process to build the character of life.[8]

Education is the most effective media to sensitize individuals of their human identity. Through education, it is possible for humankind to produce the good quality of life, the refinement of mind and soul, the tendency of positive thinking, the physical fitness, and the sense of their self-creation. Compared to other factors, education has a stronger impact in the formation of human quality.[9] 
Basically, culture is a whole and comprehensive unity with various aspects and manifestations and is understood and inherited through the learning process. Culture is a complex whole which includes knowledge, beliefs, art, law, morals, customs and any other capabilities and habits acquired by man as a member of society. Culture as a whole pattern of human behavior and the products brings of the patterns of thought, verbal, and action as well as artifacts and is very dependent on one's ability to learn and to convey such knowledge to the next generation through a variety of media, languages, and reason.[10]

Culture plays important roles in human life and society. The existence of various kinds of power in the society is an inseperable part of the culture because it produces human creativity, taste, and intention in fulfilling their lives. Every society obviously has its own culture also with its own variety and differences to meet all the needs of the community.[11] Culture regulates humans how they should act and outline their attitude in socializing with others.

Culture covers human thinking behavior. It indicates that cultures depend on the human factor. How cultures are taught depends on the education process. Education is an effort to civilize humans so that the cultural values contained in that culture can be preserved and transferred to the next generations.[12]

Culture includes all aspects learned by humans as a society. The process is done from one generation to another generation. Culture can be extinct if it is not inherited.

Cultural values can be used to build strong civilizations. Cultural approach holds an important role in building the society. Referring to the social learning theory by Bandura, it is said that culture is a pattern that can be learned. It means society can learn culture through education.[13]

Cultural construction can be formed from various cultural assets that grow and develop in society. They are well-known, adhered, and recognized as important elements in the community. Some functions of cultural noble values include: the marker of the identity of a certain community, cohesive aspects in the community, and living embodiment and value in the community.

Culture-based education is so urgently important that it should studied more deeply. In the globalization era, cultural resources as the identity marker for the survival of a group, nation and state, in globalization must not fade, degrade, or disappear. The community and nation are expected to maintain the culture under the shadow and the threat of global challenges and other serious issues.

\section{Urgency Of Culture-Based Education}

\subsection{As a Medium for Cultural Transmission}

Globalization gives a strong influence on the behavior of the Indonesian people. Many children, teenagers, and adults' attitudes are not following the morals and values of Indonesian. Many local values are gradually diminished. Therefore, it is an education that can preserve the culture of the nation.

Education is a concrete and constructive action, to restore the noble cultural values for future generations to understand and uphold. There is a close relationship of education and culture. There is no culture without education, so rebuilding Indonesian society means rebuilding Indonesian culture with its regional cultures as well. 
The cultural inheritance is done by transferring it from one generation to the next generation. Through education, human inherits the culture[14].

Education as cultural transmission is needed to preserve the culture. It is executed by humans as the organism of social culture. Culture has several characteristics; cultural behavior can be learned, it is organized within cultural patterns and taking place within generations. Culture has a material and non-material aspects. People use culture as a way of life that keeps changing from time to time

Education is an interactive process between teachers and students in society. Education as a noun, it means education has one life vision taking place in a certain society, Education is a process of spreading cultural values and kept by human and developed in a society, Education nowadays should help people to build better civilizations.[15]

Education is also seen as a cultural process that goes from one generation to another generation and adopted tradition where a certain community has not yet understood the culture through the process of enculturation and acculturation. These two processes develop a culture in a community[16].

The enculturation process takes place informally in a family, a community in a region. This process is usually done by parents to the next generation through enculturation. Acculturation is usually done through education. It is transferred from a person who knows to a person who does not know, which then he is told and the culture is adopted.

The important roles of education as a medium for cultural transmission can be seen in the process of acculturation since it becomes the main medium to introduce students to diverse cultures that should be adopted, developed, and preserved. Besides, education is also seen as a means for cultural change towards a better and dynamic direction. The education process is a civilizing process and an acculturation process. The process of acculturation is not only cultural transmission and adoption but also cultural change for the better. Education causes changes in the socio-cultural, economic, and political aspects as well as other aspects.

\subsection{Overcoming the Impact of Modernization and Globalization}

Globalization is a process, having a long history. Globalization offers an opportunity for the changing of communication, technology, production patterns, and cultural shift. Globalization is the history going through three phases. The first phase occurred during the 15 th up to 18th century when it is said the globe is round. This era is marked by human efforts to prove that the earth is round. People in Europe used to believe that the Earth was flat like a table. The agents of change during this era are muscle power, wind power, horsepower, and steam power.

Moreover, Wildan explains that the second phase occurred during the 19th up to the 20th century. The agents of change in this era are the inventions in technology and telecommunication. During this era, telegram and the telephone are invented which then are developed by the invention of satellites.

This second phase is also known as the globe is flat, where the development of technology and telecommunication provides accessibility for people to reach any places over the world. The third phase occurs in recent times, where the world is getting smaller; the shrinking globe, since people can communicate from anywhere around the world. The agents of change during this phase are information technology which is applied to open various global accesses.

The power of globalization and the development of technology as well as the cyber world have brought both positive and negative impacts for people, especially for the young generations. 
Globalization makes the world become a small village where people can connect and mutual influence. This situation opens access to various ideas and values which are difficult to be filtered. Globalization forces Indonesia to be ready to be influenced by other cultures and values. They can be perceptions believed by a group of people about anything

People cannot avoid globalization. Efforts should be provided to prepare the young generations to be ready facing their impact. By having faith, sufficient knowledge, they can get the positive impacts of globalization without having to be worried about its negatives.

Culturally, every cultural member wants others to embrace their culture. Every nation has a mission to influence other nations to be willing to accept and embrace their national culture. Therefore, either intentionally or unintentionnaly, they carry out the mission of transferring their culture. Thus, the nation needs to filter out the coming foreign cultures that are not in accordance with the national one.

As a part of the globalization process, Indonesia must be able to demonstrate its commitment dealing with this issued. The effective way to build that commitment is to prepare the young generation to have strong cultural characters rooted in the national culture and represented by the regional culture. Culture-based education is one alternative to face globalization to avoid the degradation of the national culture.

Anticipating the Weakening Power of Local Culture

Culture is a power for the Indonesian people. Cultural diversity is an undeniably real portrait of Indonesian community life. Basicall, the culture is a great power in the midst of Indonesian society. As a civilized and cultured nation, Indonesia through the government has a responsibility to uphold the culture that grows and develops in the midst of the society. Civilized society means behaving politely and refinedly.

The phenomenon of the national culture degradation does not only occur in the central region but also influence in local culture of each Indonesian region. Several regional cultures begin to disappear and are no longer known by the young generation. The above conditions are the cause cultural norm violation in the society. Many of their behaviors are in contrast to traditional and cultural values. Therefore, many young generations love western culture more than their culture.

Due to the aforementioned problems, the culture and its noble values should be socialized widely. By knowing, understanding, and inheriting the culture, the young generation can uphold and preserve it despite the strong tides of globalization. The urgency of cultural transmission through education will be able to anticipate the weakening power of local culture.

\section{Strategies For Implementing Culture-Based Education}

Cultural based education refers to the belief that culture is a fundamental part of education. This education expresses and communicates an idea and development of knowledge which is based on the culture.

The positive impact of cultural-based education will push an imaginative, metaphoric, and creative thinking process. Students participate in the learning process through various cultures. Students can learn principles of learning find meaning and get closer to their peers and environment.

In culture-based education, students can transform the result of their observation in the form of patterns and principles about nature and life. Students are not only to imitate and 
receive information but also to seek and create meaning and understanding from the information received.

Therefore, culture-based education is not only a transferring process but making the students able to create meanings that go beyond imagination.

The strategy for implementing culture-based education is through designing learning process and experience that integrate culture as the part of the process. Culture can be used as an excellent means to motivate students to apply knowledge, work cooperatively, and perceive the relations among the subjects. Thus, in culture-based education, the culture is integrated into the learning process.

Culture-based education can be implemented through three strategies: learning about culture, learning with culture, and learning through culture. First, learning about culture is learning about the surrounding culture, the environment around students, and the national and other regional cultures. The students should know, understand, study, and preserve them. Education about culture not only provides knowledge about culture but also provide cultural learning resources such as musical instruments, drama equipment specifically related to folklore and culture, etc.

Learning with culture implies that the culture and all its manifestations are designed as a medium for learning. The culture becomes the context of examples, concepts, and principles in learning. The implementation of learning strategies with culture includes the use of various forms of cultural embodiment such as the use of puppet figures 'Cepot' (humorous figures in the Sundanese puppet), which can guide students in learning, the use of 'randai' in Minangkabau culture in conveying messages of noble cultural values from Minagkabau tradition etc.

Learning through culture is designed as one form of multiple representation of learning assessment. This learning strategy gives opportunity for students to demonstrate their achievement and understanding through the embodiment of cultural diversity. The concrete form of this strategy in assessment is that students do not need to work on memorization tests but produce cultural products such as paintings about culture, poetry or songs about culture and culture and the likes. Learning through culture enables students to show the depth of their thinking, their assessment of culture, and the principles of the culture learned and express their understanding through imagination and creativity.

\section{Conclusion}

Education is a civilizing process carried out in formal, in-formal and non-formal institutions. It is also a medium for cultural conservation, transmission, and preservation. Apart from being a cultural preservation, culture-based education is seen as a means of maintaining the noble cultural values, so it will not be degraded by the times as a result of world globalization. Culture-based education creates and designs the learning environment that integrates culture in the learning process. The culture is used as a means for students to transform creative forms and principles about nature and culture. Culture-based education can be implemented through three strategies: learning about culture, learning with culture and learning through culture. 


\section{References}

[1] L. Dominelli, "Globalization, contemporary challenges and social work practice," Int. Soc. Work, vol. 53, no. 5, pp. 599-612, 2010.

[2] A. Norenzayan et al., "The Cultural Evolution of Prosocial Religions," Behav. Brain Sci., vol. 39, pp. 1-19, Dec. 2014.

[3] C. Damro, "Competitive Interdependence: Transatlantic Relations and Global Economic Governance," in The West and the Global Power Shift, Palgrave Macmillan UK, 2016, pp. 179 196.

[4] A. Alfurqan, R. Rahman, and M. Rezi, "Pendidikan Orang Dewasa Yang Dikembangkan Rasulullah,” Islam Transform. J. Islam. Stud., vol. 1, no. 1, pp. 15-29, Aug. 2017.

[5] N. Noddings, Philosophy of Education. Routledge, 2018.

[6] K. Hawkey, "Emotional intelligence and mentoring in pre-service teacher education: A literature review," Mentor. Tutoring Partnersh. Learn., vol. 14, no. 2, pp. 137-147, 2006.

[7] I. Muliati and M. Rezi, "Tujuan Pendidikan Dalam Lingkup Kajian Tafsir Tematik Pendidikan," Islam Transform. J. Islam. Stud., vol. 1, no. 2, pp. 177-190, Mar. 2018.

[8] M. L. Niess, "Transforming teachers' knowledge: Learning trajectories for advancing teacher education for teaching with technology," in Technological Pedagogical Content Knowledge: Exploring, Developing, and Assessing TPCK, Springer US, 2015, pp. 19-37.

[9] G. Biesta, "What is Education for? On Good Education, Teacher Judgement, and Educational Professionalism," Eur. J. Educ., vol. 50, no. 1, pp. 75-87, Mar. 2015.

[10] J. Street, S. Inthorn, and M. Scott, "Politics and popular culture," in From entertainment to citizenship, Manchester University Press, 2015.

[11] E. K. Edmondson, A. A. Kumar, and S. M. Smith, "Creating a Culture of Wellness in Residency," Academic Medicine, vol. 93, no. 7. Lippincott Williams and Wilkins, pp. 966-968, Jul-2018.

[12] R. Boyd, P. J. Richerson, and J. Henrich, "The Cultural Niche: Why Social Learning is Essential for Human Adaptation,” Proc. Natl. Acad. Sci. U. S. A., vol. 108, no. SUPPL. 2, pp. 10918-10925, Jun. 2011.

[13] L. Glowacki and L. Molleman, "Subsistence Styles Shape Human Social Learning Strategies," Nat. Hum. Behav., vol. 1, no. 5, Apr. 2017.

[14] D. Ilmi, "Pendidikan Karakter Berbasis Nilai-nilai Kearifan Lokal Melalui Ungkapan Bijak Minangkabau,” Islam Realitas J. Islam. Soc. Stud., vol. 1, no. 1, 2014.

[15] M. Kamal, Z. Mawardi Effendi, F. Firman, and T. Taufik, "Appearing the Motivation of Culture Research Through Developing the Minangkabau Culture Subject Based Portfolio Model," 2018, pp. 448-454.

[16] A. Muzakir, "Transformasi Pendidikan Islam ii Jambi: dari Madrasah ke Pesantren," Islam Realitas J. Islam. Soc. Stud., vol. 3, no. 1, pp. 8-20, 2017. 